\title{
Flora of Bolivia - where do we stand?
}

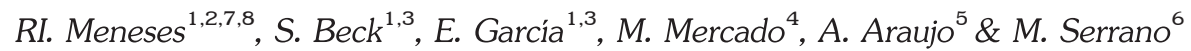

\begin{abstract}
The botanical exploration of Bolivia during the last two centuries did not leave a botanical legacy in the country. Only towards the end of the $20^{\text {th }}$ century Bolivia saw the start of the biology careers at its universities and the development of its own herbaria. Nowadays there are important herbaria in La Paz, Santa Cruz, Cochabamba and Sucre with collections ranging between 40,000 and 350,000 specimens. In 2014 a catalogue of the vascular flora of Bolivia was published under the auspices of the Missouri Botanical Garden, recording 15,345 species, of which 12,165 are native and 2,343 are endemic, while 694 are cultivated, 267 adventitious and 221 are naturalized. Endemic species of vascular plants add up to 2,343 species. The 286 families listed follow the APG III classification system. There are about 150 botanists in Bolivia interested in studying the country's rich flora. During a workshop organized in 2013 to promote a Flora of Bolivia, the participants established jointly a preliminary format for the taxonomic treatments. The Flora of Bolivia is planned to be an electronic, open access publication with international participation. The World Flora represents a challenge that must be tackled by circumscribing, verifying and recording all species known within our territory, and it is expected that it will have positive repercussions from and towards the ongoing Flora of Bolivia, in a similar way as the long running series of the Flora Neotropica has provided a wider picture that can be adapted and modified to fit our particular country.
\end{abstract}

Key words: Flora, Bolivia, Chaco, Amazonia, endemics.

\section{Resumo}

A exploração botânica da Bolívia durante os últimos dois séculos não deixou um legado botânico no país. Apenas no final do século 20 o país começou a formar biólogos nas suas universidades e a desenvolver os seus acervos muselógicos. Atualmente existem herbários importantes em La Paz, Santa Cruz, Cochabamba e Sucre, com coleções acumulando entre 40 e 350 mil espécimes. O Catálogo da Flora Vascular da Bolívia, publicado em 2014 sob os auspícios do Missouri Botanical Garden, registrou 15.345 espécies de plantas, das quais 12.165 são nativas, enquanto 694 são cultivadas, 267 adventícias e 221 naturalizadas. Um total de 2.343 espécies de plantas vasculares endêmicas foi registrado para o país. As 286 famílias listadas seguem o sistema de classificação APG III. Existem cerca de 150 botânicos ativos na Bolívia, cujo interesse é estudar a rica flora do país. Uma oficina foi organizada em 2013 com intuito de promover a Flora da Bolívia, durante a qual um formato preliminar para os tratamentos taxonômicos foi estabelecido pelos participantes. O intuito é de apresentar a Flora da Bolívia como uma publicação eletrônica e de acesso aberto ao público contando com participantes internacionais. Enquanto representa um grande desafio para a comunidade botânica mundial, a Flora do Mundo objetiva circunscrever, verificar e registrar todas as espécies conhecidas em nosso território, e espera-se que esse ambicioso projeto tenha repercussão positiva em relação à Flora da Bolívia, da mesma forma na qual a longa série Flora Neotropica tem gerado um esquema mais amplo que pode ser adaptado e modificado para servir ao nosso país em particular.

Palavras-chave: Flora, Bolívia, Chaco, Amazônia, endêmica.

\footnotetext{
${ }^{1}$ Herbario Nacional de Bolivia, Campus Universitario, Cota Cota, calle 27, Casilla 10077, La Paz, Bolivia.

${ }^{2}$ Museo Nacional de Historia Natural. Cota Cota, calle 26, Casilla 8706, La Paz, Bolivia.

${ }^{3}$ Instituto de Ecología, Universidad Mayor de San Andrés, La Paz, Bolivia.

${ }^{4}$ Herbario Nacional Forestal Martín Cárdenas - Centro de Biodiversidad y Genética, Universidad Mayor de San Simón, Cochabamba.

${ }^{5}$ Herbario Regional del Oriente, Universidad Autónoma Gabriel René Moreno, Santa Cruz.

${ }^{6}$ Herbario del Sur, Universidad Mayor Real y Pontificia de San Francisco Xavier, Chuquisaca.

${ }^{7}$ Correo Central Casilla 10077, Campus Universitario Cota Cota, calle 27, La Paz, Bolivia.

${ }^{8}$ Author for correspondence: rosaiselameneses11@gmail.com
} 


\section{Introduction}

Bolivia is among one of the most biodiverse countries in the world, home to around 17,000 species of vascular plants (Beck 1998). Highlighted by Lack (2012) as the only South American country that did not attempt to compile a complete floristic account until the end of the past century, as the in-country study of the Bolivian flora has started particularly late (Meneses et al. 2013). As an example, the Biology Course at the Universidad Mayor de San Andrés, La Paz, started only in 1972, while the Herbario Nacional de Bolivia (LPB) was created in 1984 and is only 31 years old. Other herbaria in the country are in a similar situation, contrasting with herbaria in neighbouring countries, such as the Instituto de Botánica Darwinion (SI) and the Museo de La Plata (LP), in Argentina, and the Jardim Botânico do Rio de Janeiro (RB) and Museu Nacional (R) in Brazil, all with over a hundred years of age and continuously developing collection and research activities, as well as a long tradition of forming taxonomists. These countries have created diverse initiatives to prepare local and regional floras and vegetation surveys (Hoehne 1940-1965; Reitz 1965; Correa 1969-1999; Klein 1978; Zuloaga \& Morrone 1996,1999; Wanderley et al. 2001).

A Flora is fundamental to enable a country to document its natural patrimony, be it as a guide for sustainable use of its plant resources or to inforce conservation measures to protect and manage plant diversity, being a data source for future basic or applied studies.

\section{Brief history of Bolivian botany}

The year of 1978 has marked the start of systematic floristic surveys in La Paz (LPB) through international collaboration between Bolivia, Germany and the United States, resulting in the collection of over 350,000 specimens of vascular plants (ferns, gymnosperms and angiosperms) and a smaller number of non vascular plants. These collections partially document the floristic richness of the country, while a group of more regional herbaria in Cochabamba, Santa Cruz and Sucre comprise respectively 60,000, 160,000 and 40,000 specimens (Tab. 1), complementing the overall picture.

It is important to understand that the Herbario Nacional de Bolivia (LPB) was created as part of an agreement between the Instituto de Ecología de la Universidad Mayor de San Andrés and the Museo Nacional de Historia Natural, therefore it aims to incorporate valuable ecologic information to the floristic inventories, comprising auto and synecology data regarding species, as well as etnobotanical data in the form of use references. Such integration allows for a wider appreciation of the floristic diversity and also of the different vegetation types found in Bolivia, resulting in many publications and in recent comments on biogeography and evolution (Fernández et al. 2015; Maldonado et al. 2015; Gallegos et al. 2014; Saavedra et al. 2014; ApazaQuevedo et al. 2013; Cuesta et al. 2012; Beck et al. 2010; Zenteno-Ruiz et al. 2009; Fuentes Claros 2006; Moraes et al. 2006).

The recently published Catalogue of Vascular Plants (Jørgensen et al. 2014) represents an important milestone that will constitute the base for the preparation of the Flora of Bolivia. This publication took 15 years of intermittent work to be completed, and was carried under a broad collaboration from different institutions worldwide and published under the auspices of the Missouri Botanical Garden (MO), with the contribution of 221 specialists and 53 reviewers. The general plan for the Catalogue followed the system created for the Peru and Ecuador catalogues (Brako \& Zarucchi 1993; Jørgensen \& León-Yánez 1999). In Bolivia, 44 botanists from the Herbario Nacional de Bolivia (LPB), Herbario Nacional Forestal Martín Cárdenas (BOLV), Herbario Regional del Oriente (USZ) and the Herbario del Sur de Bolivia (HSB) were responsable for treatments at family or generic level.

Table 1 - Number of specimens deposited in major Bolivian Herbaria

\begin{tabular}{lllc}
\hline Department & Herbaria & Acronym & Specimen \\
\hline La Paz & Herbario Nacional de Bolivia & LPB & 350,000 \\
Cochabamba & Herbario Nacional Forestal Martín Cárdenas & BOLV & 60,000 \\
Santa Cruz & Herbario Regional del Oriente & USZ & 160,000 \\
Chuquisaca & Herbario del Sur de Bolivia & HSB & 40,000 \\
\hline
\end{tabular}


Preparation of the Flora of Bolivia

As a basis for the preparation of the Flora of Bolivia, the published catalogue (Jørgensen et al. 2014) contains a synopsis of the vascular flora of Bolivia as it is known today, providing synonymy for species, bibliographic references for Bolivia, life-forms, origin, regional distribution, vegetation zones, altitudinal distribution and by geopolitical division, infraspecific taxa and common names when available. It is possible to access the electronic version in the webpage of the Missouri Botanical Garden (TROPICOS 2015). The data is managed as part of the TROPICOS, therefore it can be updated, added to and corrected in a dynamic way.

The Bolivian catalogue documents 286 families arranged following the APG III (2009) classification system, comprising 15,345 species of which 12,165 are native species, while 694 are cultivated, 267 adventitious and 221 naturalized (Tab. 2), and 112 further putative species records not yet confirmed for the country. The number of endemic species currently recorded for Bolivia is 2,343 , slightly less than $16 \%$ of the total species number. The present count departed from an initial total of 47,974 names recorded for Bolivia, amalgamating information from the catalogue of ferns and flowering plants of Bolivia (Foster 1958) and the Guía de árboles de Bolivia (Killeen et al. 1993) with records from Tropicos (2015) and The International Plant Names Index (IPNI 2015 ) either published from or with distribution referred to Bolivia. The major groups (Tab. 3) are 14,157 angiosperms, 1,145 ferns and 43 gymnosperms, most of the last introduced and/or cultivated. Orchidaceae, Asteraceae and Fabaceae

Table 2 - Vascular plants of Bolivia summarized according to category

\begin{tabular}{ll}
\hline Category & $\mathbf{N}^{\mathbf{o}}$ species \\
\hline Accepted & 15,345 \\
Native & 12,165 \\
Endemic & 2,343 \\
Cultivated & 694 \\
Adventicious & 267 \\
Naturalized & 221 \\
\hline *Several species are recorded in different categories, therefore the total \\
number is higher than the accepted species number. Categorization according \\
to Jørgensen et al. 2014
\end{tabular}

contribute over 1,000 species and six of the largest genera (over 100 species), where Solanum alone comprises 192 species (Tab. 4, 5).

Considering the 9 major geopolitical subdivisions, or departments (Fig. 1) of Bolivia, the four southwestern ones, La Paz, Oruro, Potosi and partly Cochabamba include the majority of the Andean highlands, while Chuquisaca, the eastern part of Cochabamba and La Paz are also home to the interandean valleys, Tarija, Chuquisaca and Santa Cruz are home to the Chaco (related to the Brazilian Pantanal), while Santa Cruz spans from Chaco in the south, Savanna in the far east, and transitional rainforest reaching the mostly Amazonian departments of Pando and Beni (CEDIB 2015). At present, La Paz features the highest number of species, while the entirely Amazonian department of Pando, with meagre 2,000 species records (Tab. 6), is likely to be undercollected. The same is true in the case of the vast Beni department (Tab. 5, Fig. 2) and the Andean highlands in Oruro and Potosi (Fig. 2), just to exemplify the areas showing sparse collecting activities in the map prepared from databased herbarium records. Even considering the harsh climatic conditions at high altitudes,

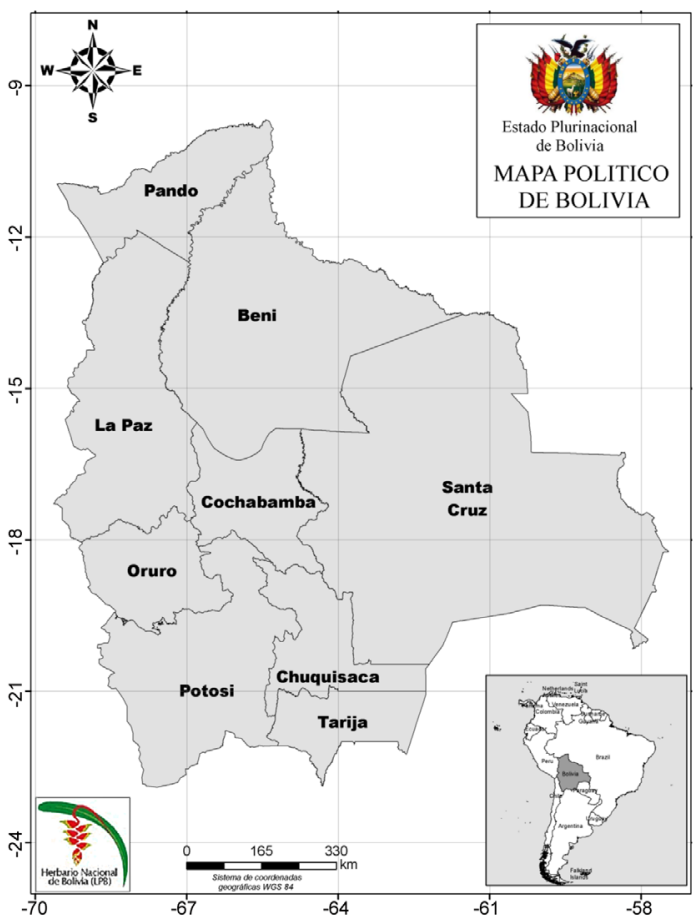

Figure 1-Map of Bolivia highlighting the departaments. 


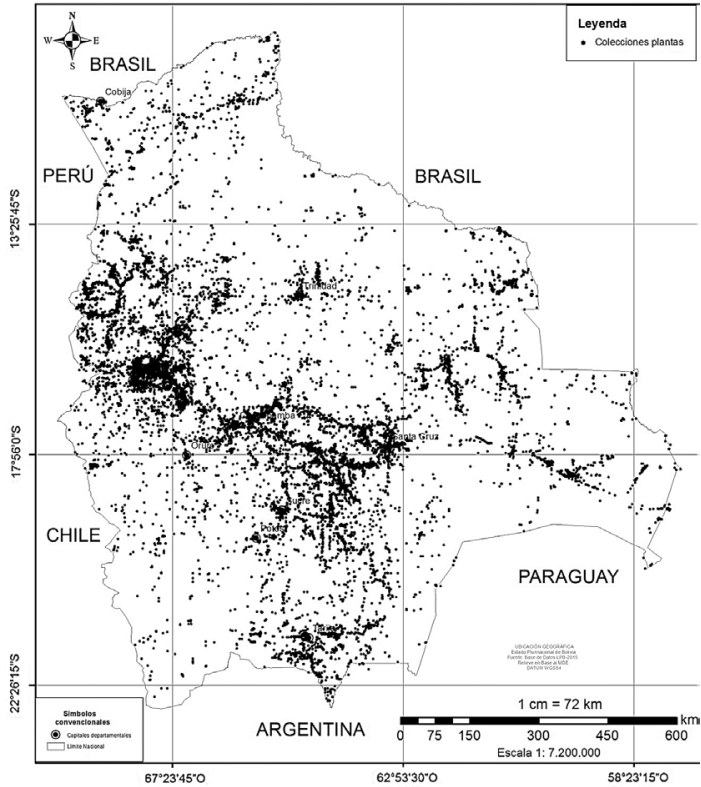

Figure 2 - Vascular specimen collections according to the LPB herbarium database, July 2015.

Table 3 - Vascular plant groups in Bolivia

\begin{tabular}{llll}
\hline Groups & Families & Genera & Species \\
\hline Ferns & 33 & 126 & 1,145 \\
Gymnosperms & $8^{*}$ & 20 & 43 \\
Angiosperms & 245 & 2,636 & 14,157 \\
\hline Total & 286 & 2,782 & 15,345 \\
\hline${ }^{*}$ including 4 introduced families & &
\end{tabular}

Table 4 - Ten top families of vascular plants in Bolivia

\begin{tabular}{ll}
\hline Families & $\mathbf{N}^{\mathbf{0}}$ species \\
\hline Orchidaceae & 1,263 \\
Asteraceae & 1,256 \\
Fabaceae & 1,114 \\
Poaceae & 962 \\
Malvaceae & 445 \\
Rubiaceae & 429 \\
Cyperaceae & 348 \\
Solanaceae & 341 \\
Melastomataceae & 325 \\
Euphorbiaceae & 322 \\
\hline
\end{tabular}

Andean altiplano highlands feature 1,565 species, while the Andean slopes 9,253 species, more than in the lowlands with 8,453 species (Jørgensen et al. 2014). A breakdown of species numbers by altitudinal quota (Tab. 7) shows the decrease in species number with altitude above two thousand meters and that, at the upper limit (above 5,000 m), 33 species have been recorded.

Bolivia currently counts with approximately 150 botanists, mostly Biology graduates from the state universities of the Departments of La Paz, Cochabamba and Santa Cruz, but also agronomists and foresters from the universities in Beni, Chuquisaca and Tarija.

\section{Towards a Flora of Bolivia}

The publication of the Bolivian catalogue edited by Jørgensen et al. (2014) has motivated the country's herbaria to pursue the organization of knowledge regarding botanical richness and diversity. These tasks are gaining momentum as it is understood that a Flora is important and most necessary as the baseline for basic and applied plant studies.

A workshop "Towards a Flora of Bolivia" was organized in April 2013, with the participation of 40 botanists from Bolivia and other countries. The curators and representatives of the herbaria of Cochabamba (BOLV), Sucre (HSB), La Paz (LPB), Santa Cruz (USZ), Cobija, Oruro and Potosí were present alongside botanists that have supported the study of the Bolivian Flora for many years: the coordinator of the Madidi Project from the Missouri Botanical Garden (MBG), the author and editor of the Flora de Amboró from the New York Botanical Garden (NY), the coordinator of several Darwin Initiative projects from the Royal Botanic Gardens, Kew (K) and Oxford University and the Director of the Berlin Botanical Garden (BGBM).

The results from the workshop were published by Meneses et al. (2013) to increase their visibility. Some of the conclusions from this meeting are summarized below.

By consensus of all participants the Flora of Bolivia must be a publication of the highest scientific rigour and involving collaboration and communication with specialists worldwide.

The task of preparing a flora is arduous for the botanists; the existence of a Flora of Bolivia will create the opportunity to develop and gather the scientific knowledge regarding the species, 
Table 5 - Ten top genera of vascular plants in Bolivia

\begin{tabular}{lc}
\hline Genera & $\mathbf{N}^{\mathbf{0}}$ species \\
\hline Solanum & 192 \\
Miconia & 141 \\
Epidendrum & 128 \\
Elaphoglossum & 127 \\
Peperomia & 123 \\
Tillandsia & 104 \\
Senecio & 99 \\
Thelypteris & 96 \\
Paspalum & 95 \\
Piper & 93 \\
\hline
\end{tabular}

Table 6 - Species number and area of the 9 departments of Bolivia

\begin{tabular}{lcc}
\hline Departament & $\begin{array}{c}\text { Species } \\
\text { number }\end{array}$ & $\begin{array}{c}\text { Approx. area } \\
\left(\mathbf{k m}^{2}\right)\end{array}$ \\
\hline La Paz & 9,272 & 120,000 \\
Santa Cruz & 7,817 & 357,000 \\
Cochabamba & 5,888 & 52,000 \\
Beni & 3,626 & 288,00 \\
Chuquisaca & 2,577 & 46,000 \\
Tarija & 2,554 & 35,000 \\
Pando & 2,001 & 60,000 \\
Potosí & 997 & 98,000 \\
Oruro & 442 & 43,000 \\
\hline
\end{tabular}

thus facilitating future species identification, knowledge dissemination towards conservation and sustainable management of the plant resources.

The workshop also provided an opportunity for the participants to establish the format for the taxonomic treatments, that was prepared in collaboration and accepted as a joint decision. The treatments of the Flora will include the accepted scientific name and selected synonyms according to the International Code for Nomenclature of Algae, Fungi and Plants (McNeill et al. 2012). The morphologic descriptions will be based in Bolivian specimens and include the most relevant characters compiled in a relatively short text (200300 words). Additional data will include habitat information, autoecologic information regarding the taxa (phenology, pollinators when known, etc.), the common names and known uses. Identification keys will include representative morphologic characters of vegetative and reproductive parts. Complementary ecologic information may be given in order to subsidise the species identification. A representative selection of up to 20 specimens will be used to fundament the specific or infraspecific taxonomic circumscription used in the flora. Distribution maps will contain georeferenced points based on specimens found in the available national and international databases containing Bolivian records after being examined by authors of the treatments. Illustrations will be provided to depict at least each genus, and may be either photographs or line-drawings.

The classification will be based on up to date phylogenetic knowledge (APG III 2009) to order and plant family level. Generic classification will preferably consider monophyletic groups, bearing in mind that this level of information is not yet available for all plant groups.

The Flora of Bolivia has been planned as an electronic, open access publication. The first fascicles will be prepared with groups comprising relatively few species, for which there are already Bolivian and foreign specialists engaged in studies, as for example families Amaranthaceae, Arecaceae, Lentibulariaceae, and selected groups of Orchidaceae and Poaceae. The participation of Bolivian botanists is strongly encouraged, however

Table 7 - Altitudinal distribution of the vascular plants of Bolivia

\begin{tabular}{lc}
\hline Altitude (m a.s.l.) & Species number \\
\hline $0-500$ & 7,150 \\
$500-1,000$ & 4,972 \\
$1,000-1,500$ & 4,316 \\
$1,500-2,000$ & 3,902 \\
$2,000-2,500$ & 3,536 \\
$2,500-3,000$ & 3,331 \\
$3,000-3,500$ & 2,650 \\
$3,500-4,000$ & 1,855 \\
$4,000-4,500$ & 881 \\
$4,500-5,000$ & 410 \\
$>5000$ & 33 \\
\hline
\end{tabular}


we are aware that they are very few when taking into account the size of the task ahead.

Bolivia has a positive track record with the Flora Neotropica Organization that helped the country, back in 1984, to found the Herbario Nacional de Bolivia (LPB), uniting collections, human capacity and infrastructure. The annual Flora Neotropica meeting in the Andes supported local herbaria and created new regional ones, enhancing the profile of botanical research in the country.

\section{Conclusion}

As all other tropical countries that are part of the World Flora, Bolivia needs to engage in the preparation of its national flora in order to contribute towards the final account at a global level. We do hope that the international scientific community and the national authorities are able to support the preparation of our Flora alongside the World Flora Project (Jackson \& Miller 2015). Bolivian taxonomists could also contribute directly towards the World Flora, especially in particular groups such as the high-andean plants from the humid slopes of the Andes, highland wetlands and of the mostly endemic groups with a centre of diversity in the region, such as the Chloranthaceae, Cunoniaceae and Hypseocharitaceae.

The contribution to the World Flora is seen as a positive challenge by the Bolivian botanical community. As the verification and recording of species started by the Bolivian Catalogue (Jørgensen et al. 2014) continues to be improved and the Bolivian taxa are better circumscribed, we seek to unite our knowledge across the borders into neighbouring countries. Our relatively young botanical institutions and community are keen to participate in the elaboration of widely accessible documents for all stakeholders interested in contributing towards the survival of humankind that is today threatened by the increasing loss of habitats, biodiversity and compromising of the Earth's ecologic processes.

\section{References}

Apaza-Quevedo, A.; Schleuning, M.; Hensen, I.; Saavedra, F. \& Durka, W. 2013. Forest fragmentation and edge effects on the genetic structure of Clusia sphaerocarpa and C. lechleri (Clusiaceae) in tropical montane forests. Journal of Tropical Ecology 29: 321-329.

APG III. 2009. The Angiosperm Phylogeny Group III. (Brigitta Bremer, Kåre Bremer, Mark W. Chase, Michael F. Fay, James L. Reveal, Douglas E.
Soltis, Pamela S. Soltis y Peter F. Stevens, además colaboraron Arne A. Anderberg, Michael J. Moore, Richard G. Olmstead, Paula J. Rudall, Kenneth J. Sytsma, David C. Tank, Kenneth Wurdack, Jenny Q.-Y. Xiang y Sue Zmarzty). An update of the Angiosperm Phylogeny Group classification for the orders and families of flowering plants. Botanical Journal of the Linnean Society 161: 105-121.

APG III. 2009. An update of the Angiosperm Phylogeny Group classification for the orders and families of flowering plants: APG III. Botanical Journal of the Linnean Society 161: 105-121.

Beck, S.G. 1998. Floristic inventory of Bolivia An indispensable contribution to sustainable development. In: Barthlott, W. et al. (eds.). Biodiversity: a challenge for development research and policy. Springer, Heidelberg. Pp. 243-267. ISBN 978-3-662-06071-1.

Beck, S.G.; Domic, A.; García, C.; Meneses, R.I.; Yager, K. \& Halloy, S. 2010. El Parque Nacional Sajama y sus plantas. Herbario Nacional de Bolivia. La Paz. 250p.

Brako, L. \& Zarucchi, J.L. 1993. Catalogue of the flowering plants and Gymnosperms of Peru. Monographs in Systematic Botany from the Missouri Botanical Garden 45: i-xl, 1-1286.

CEDIB. 2015. Ecorregiones de Bolivia. Available at <http://www.cedib.org/post type mapas/ ecorregiones/>. Access on 23 September 2015.

Correa, M.N. (ed.). Flora patagónica. INTA, Buenos Aires. Pp. 1969-1999.

Cuesta, F.; Muriel, P.; Beck, S.G.; Meneses, R.I.; Halloy, S.; Salgado, S.; Ortíz, E. \& Becerra, M.T. (eds.). 2012. Biodiversidad y cambio climático en los Andes tropicales. Coformacion de un red de investigación para monitorear sus impactos y delinear acciones de adaptación. Red GLORIAAndes, Lima-Quito. 180p.

Fernández, M.; Navarro, L.M.; Apaza-Quevedo, A.; Gallegos, S.C.; Marques, A.; Zambrana-Torrelio, C.; Wolf, F.; Hamilton H.; Aguilar-Kirigin, A.J.; Aguirre, L.F.; Alvear, M.; Aparicio, J.; ApazaVargas, L.; Arellano, G.; Armijo, E.; Ascarrunz, N.; Barrera, S.; Beck, S.G.; Cabrera-Condarco, H.; Campos-Villanueva, C.; Cayola, L.; Flores-Saldana, N.P.; Fuentes, A.F.; García-Lino, M.C.; Gómez, M.I.; Higueras, Y.S.; Kessler, M.; Ledezma, J.C.; Limachi, J.M.; López, R.P.; Loza, M.I.; Macía, M.J.; Meneses, R.I.; Miranda, T.B.; Miranda Calle, A.B.; Molina-Rodriguez, R.F.; Moraes R.M.; MoyaDiaz, M.I.; Ocampo, M.; Perotto-Baldivieso, H.L.; Plata, O.; Reichle S.; Rivero, K.; Seidel, R.; Soria, L.; Terán, M.F.; Toledo, M.; Zenteno-Ruiz, F.S. \& Pereira, H.M. 2015. Challenges and opportunities for the BolivianBiodiversity Observation Network. Available at $<$ http://dx.doi.org/10.1080/14888386.2 015.1068710>. Access on 1 October 2015. 
Foster, R.C. 1958. A catalogue of the ferns and flowering plants of Bolivia. Contribution of the Gray Herbarium 184: 91-102.

Fuentes Claros, A.F. 2005 [2006]. Una introducción a la vegetación de la región del Madidi. Ecología de Bolivia 40: 1-31.

Gallegos, S.C.; Hensen, I. \& Schleuning, M. 2014. Secondary dispersal by ants promotes forest regeneration after deforestation. Journal of Ecology 102: 659-666.

Hoehne, F.C. 1940-1965. Flora Brasilica. Secretaria de Agricultura do Estado de São Paulo, São Paulo.

IPNI. 2015. The International Plant Names Index. Available at $<$ http://www.ipni.org $>$. Access 1 July 2015.

Jørgensen, P.M. \& León-Yánez, S. (eds.). 1999. Catalogue of the vascular plants of Ecuador. Monographs in Systematic Botany from the Missouri Botanical Garden 75: i-viii, 1-1182.

Jørgensen, P.M.; Nee, M.H. \& Beck, S.G. (eds.). 2014. Catálogo de plantas vasculares de Bolivia, Monographs in Systematic Botany from the Missouri Botanical Garden 127: i-viii, 1-1744.

Killeen, T.; Garcia, E. \& Beck, S.G. (eds.). 1993. Guía de árboles de Bolivia. Herbario Nacional de Bolivia, Missouri Botanical Garden, La Paz. 958p.

Klein, R.M. 1978. Mapa fitogeográfico do estado de Santa Catarina. In: Reitz, R. (ed.). Flora ilustrada catarinense. Herbário Barbosa Rodrigues, Itajaí. $24 \mathrm{p}$.

Lack, W. 2012. Flora projects - a never ending synthesis. In: Lack, W. \& Grotz K. (eds.), Flora's treasures recording the green world. Botanisches Museum Berlin, Dahlem. Pp. 10-11.

Maldonado, C.; Molina, C.I.; Zizka, A.; Persson, C.; Taylor, C.M.; Albán, J.; Chilquillo, E.; Rønsted, N. \& Antonelli, A. 2015. Estimating species diversity and distribution in the era of Big Data: to what extent can we trust public databases? Global Ecology and Biogeography 24: 973-984.

McNeill, J.; Barrie, F.R.; Buck, W.R.; Demoulin, V.; Greuter, W.; Hawksworth, D.L.; Herendeen, P.S.; Knapp, S.; Marhold, K.; Prado, J.; Prud'homme Van Reine, W.F.; Smith, G.F.; Wiersema, J.H. \& Turland, N.J. (eds.). 2012. International Code of Nomenclature for algae, fungi and plants (Melbourne Code) adopted by the Eighteenth International Botanical Congress Melbourne,
Australia, July 2011. Regnum Vegetabile 154. Koeltz Scientific Books, Germany. 140p.

Meneses R.I.; Borsch T.; Ortuño T. \& Fuentes, A. 2013. Hacia una flora de Bolivia. Revista de la Sociedad Boliviana de Botánica 7: 97-100.

Moraes R.M.; Øllgaard, B.; Kvist, L.P.; Borchsenius Kristensen, F. \& Balslev, H. (eds.). 2006. Botánica económica de los Andes centrales. Universidad Mayor de San Andrés, La Paz. Pp. 1-557.

Reitz, R. 1965. Plano de coleção. In: Reitz, R. (ed.). Flora ilustrada catarinense. Herbário Barbosa Rodrigues, Itajaí. 71p.

Saavedra, F.; Hensen, I.; Beck, S.G.; Böhning-Gaese, K.; Lippok, D.; Töpfer, T. \& Schleuning, M. 2014. Functional importance of avian seed dispersers changes in response to human induced forest edges in tropical seed dispersal networks. Oecologia 176:83748. DOI 10.1007/s00442-014-3056-x.

Tropicos. 2015. Bolivia catalogue/Catálogo de las plantas vasculares de Bolivia. Missouri Botanical Garden. Available at $<$ http://www.tropicos.org/Project/BC $>$. Access on 1 July 2015.

Wanderley, M.G.L.; Shepherd, G.J. \& Giulietti, A.M. 2001. Flora fanerogâmica do Estado de São Paulo. FAPESP/ HUCITEC, São Paulo. Pp. 57-140.

Wyse Jackson, P. \& Miller, J.S. 2015. Developing a World Flora Online - a 2020 challenge to the world's botanists from the international community.Rodriguésia 66: 939-946.

Zenteno-Ruiz, F.S.; Beck, S.G.; López, R.P. \& Gallegos, S. 2009. Caracterización de la vegetación y de la diversidad florística de la cuenca alta del río Bermejo, Tarija: implicaciones para su conservación. In: Beck, S.G. et al. (eds.). "Biodiversidad y Ecología para la Conservación en Bolivia - Simposio de los 30 años del Instituto de Ecología”. Instituto de Ecología, Universidad Mayor de San Andrés, La Paz. Pp. 162-173.

Zuloaga, F.O. \& Morrone, O. (eds.). 1996. Catálogo de las plantas vasculares de la República Argentina. I. Pteridophyta, Gymnospermae \& Angiospermae (Monocotyledoneae). Monographs in Systematic Botany from the Missouri Botanical Garden 60: 1-323.

Zuloaga, F.O. \& Morrone, O. (eds.). 1999. Catálogo de las plantas vasculares de la República Argentina. II. Angiospermae (Dicotyledoneae). Monographs in Systematic Botany from the Missouri Botanical Garden 64: 1-1269. 
